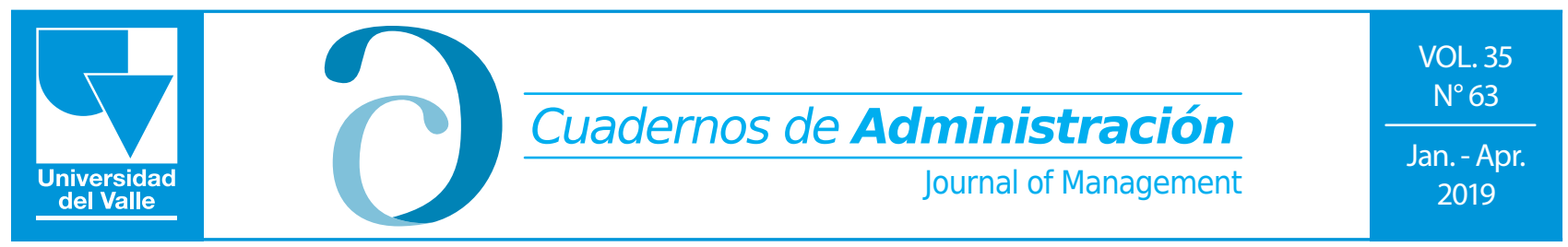

Print ISSN: 0120-4645 / E-ISSN: 2256-5078 / Short name: cuad.adm. / Pages: 42-54

Faculty if Administration Sciences / Universidad del Valle / Cali - Colombia

\title{
Mud, value and welfare. An economic estimation of the impact in the Anchicayá river basin*
}

\author{
Lodo, valor y bienestar. Una estimación económica del impacto \\ en la cuenca del río Anchicayá
}

\author{
Boue, valeur et bien-être. Une estimation économique de l'impact \\ sur le bassin de l'Anchicayá
}

\author{
Raúl Cortés Landázury ${ }^{1}$ \\ Full Professor, Department of Economic Sciences, Universidad del Cauca, Popayán, Colombia \\ ORCID iD: https://orcid.org/0000-0003-2923-0523. e-mail: rcortes@unicauca.edu.co
}

\section{Alejandra Ríascos López²}

Member, research group Desarrollo y Políticas Públicas (Polinomía-Development and Public Policy), Universidad del Cauca, Colombia. ORCID iD: https://orcid.org/0000-0002-2048-065X. e-mail: priascos@unicauca.edu.co

\section{Willian Idrobo Salazar ${ }^{3}$}

Member, research group Desarrollo y Políticas Públicas (Polinomía-Development and Public Policy)

ORCID iD: https://orcid.org/0000-0003-3251-1238. e-mail: willianidrobo@unicauca.edu.co

Article of Scientific and Technological Research, PUBLINDEX-COLCIENCIAS classification

Submitted: $26 / 08 / 2018$

Reviewed: 23/11/2018

Accepted: $14 / 12 / 2018$

Core topic: Economics

JEL classification: 051

DOI: https://doi.org/10.25100/cdea.v35i63.6939

\section{Abstract}

The implementation of modernizing projects in the midst of rural societies, in parallel with the great benefits in terms of regional and national growth, generates threats to local socio-ecological sustainability. Such is the case of the discharge of sludge generated by the Bajo Anchicayá dam in the Colombian Pacific in 2001. The economic assessment of the environmental impact is given to address the past, present and future impacts in cases such as the one described above where environmental goods and services as well as supervening exchange relationships are not guided by the logic of the market. However, this article attempts to account for the direction and scope of such effects, based on a pricing chrematistics and compensatory assessment claimed by court litigation by the affected communities un-

* Part of this document, gives continuity to the research work in the classroom and advanced collaborative learning in the lecture of environmental economics and environmental evaluation of projects that is taught at the Universidad del Cauca. With this support, the expert opinion was fed by the Contentious Administrative Tribunal of the Valle del Cauca (2014) for the estimation of the damage caused by background discharges in the Anchicayá basin.

1 Economist, Universidad del Valle, Doctor in Economícs, Universidad Nacional Autónoma de México. Director, research group on Development and Public Policies: Polinomía, research incubator mentor, Panarquía, Universidad del Cauca, Colombia.

2 Economist, Universidad del Cauca, Popayán, Colombia.

3 Economist, Universidad del Cauca, Colombia. 
der information restrictions and slightly commercialized economic dynamics. At the end, it was possible to establish the operability of the assessment methods, type of stated preferences, which simulate market conditions in favor of alternative strategies such as the transfer of benefits that while not infallible, with the lack of environmental accountancy, try to respect the spatial, time and socio-ecological complexity of territories such as the Pacific Coast.

Keywords: Environmental economics, Economic valuation, Environmental impact, Total economic value.

\section{Resumen}

La implementación de proyectos modernizantes en medio de sociedades rurales, paralelamente a los grandes beneficios en materia de crecimiento regional y nacional, genera amenazas en la sostenibilidad socioecológica local. Tal es el caso, de la descarga de lodos generada por la represa del Bajo Anchicayá en el Pacífico Colombiano en el año 2001. La valoración económica del impacto ambiental, está dada a atender los impactos pasados, presentes y futuros, en casos como el descrito donde los bienes y servicios ambientales así como, las relaciones de intercambio sobrevinientes, no están guiadas bajo las lógicas del mercado; sin embargo, el presente artículo intenta dar cuenta de la dirección y los alcances de tales efectos, a partir de una tasación crematística y compensatoria reclamada judicialmente por las comunidades afectadas bajo restricciones de información y dinámicas económicas levemente mercantilizadas. A la postre, se pudo establecer la baja operatividad de los métodos de valoración tipo preferencias declaradas, que simulan condiciones de mercado, en favor de estrategias alternas como la transferencia de beneficios que si bien no resultan infalibles, a falta de sistemas de contabilidad ambiental, tratan de respetar la complejidad espacial, temporal y socioecológica de territorios como la costa pacífica colombiana.

Palabras clave: Economía ambiental, Valoración económica, Impacto ambiental, Valor económico total.

\section{Résumé}

La mise en œuvre de projets de modernisation au sein des sociétés rurales, parallèlement aux grands bénéfices en termes de croissance régionale et nationale, produit des menaces pour la durabilité socio-écologique locale. C'est le cas des rejets de boues générés par le barrage de Bajo Anchicayá dans le Pacifique colombien en 2001. L'évaluation économique de l'impact environnemental est donnée pour prendre en compte les impacts passés, présents et futurs, dans des cas comme celui décrit où les biens et services environnementaux ainsi que les relations d'échange survivantes ne sont pas guidés par les logiques du marché ; néanmoins, le présent article tente de rendre compte de la direction et des portées de ces effets, à partir d'une évaluation chrématis- tique et compensatoire demandée judiciairement par les communautés affectées sous des restrictions d'information et une dynamique économique légèrement marchandisée. En fin de compte, il a été possible d'établir la faible opérabilité des méthodes d'évaluation de type préférence déclarée, qui simulent les conditions du marché, en faveur de stratégies alternatives telles que le transfert de bénéfices qui, bien que non infaillibles, en l'absence de systèmes de comptabilité environnementale, cherchent à respecter la complexité, spatiale, temporelle et socio-écologique des territoires comme la côte pacifique colombienne.

Mots clés: Économie de l'environnement, Évaluation économique, Impact environnemental, Valeur économique totale.

\section{Introduction}

Every living being needs an adequate environment for their proper development; this can be defined in terms of a certain range of values for each of the factors that affect the individual, species or community in relation to their environment (Garmendia and Crespo, 2005). Human beings, in particular, are vulnerable to changes in the environment, likewise their ability to defend themselves against disturbances depends on their social, political and economic condition, while the way in which communities and ecosystems value the natural environment is derived according to the structure or function of the same, so that a patent can be made at different scales (Botelhoa, Ferreirab, Limac, Costa Pintod, and Sousae, 2017).

Hydroelectric energy is considered a "tool for economic development" since it has a multifunctional character, since it has some "advantages" in the environmental field when compared to conventional energy sources, but this does not mean that it does not generate damages as well (Botelhoa et al, 2017). If we analyze the specific case of the Anchicayá hydroelectric project that counts with two dams, Bajo and Alto Anchicayá, on $21^{\text {st }}$ of July of 2001, the Empresa de Energía del Pacífico (the Pacific Energy Company) EPSA- S.A.E.S.P performed an illegal discharge of approximately 500,000 cubic meters of mud from the Bajo Anchicayá dam on the river Ministerio del medio ambiente y desarrollo sostenible (Minambiente, 2007). The spill, caused by the opening of the 
dam's gates caused material and immaterial damages along approximately $60 \mathrm{~km}$ on both sides of the river, affecting 15 communities and approximately 3087 inhabitants of the riverbank (Defensoría del Pueblo, 2007).

After this issue, the development of the problem and the sequential emergence of the conflict led to judicial litigation with different assessments of the phenomenon, one of the most important leaned on the combination of economic, moral and environmental damage, reason why the appraisal of losses such as those generated by the operation of the hydroelectric will tend to worsen due to the biophysical characteristics of the basins belonging to the rivers of the Pacific region and the singularities of the social groups that inhabit this territory.

However, the socio-economic dynamics of the basin inhabited by farmers and Afrodescendant communities, accustomed to the culture of agricultural products for their own consumption, is far from structures and institutions cut across with transactions of commercial nature, so the logic of use value survives and very slightly the exchange value does so; to this adds up the time distance and the difficulty of performing simulations that reveal market estimates because, among other things, many of those affected may already be dead or absent due to migration and displacement given the dynamics of the conflict in the area. That being said, it is worth asking: What kind of methodological strategy is appropriated for the circumstances of this context? What would the economic analysis have taken into account to respond the judicial lawsuit? And finally, what will be the updated values that will compensate the communities in question?

To answer these questions, this document discusses the fundamental elements of the theory of value, supported by an approximate model of damages or externalities estimation with secondary information and documentary analysis. In this way, it begins with a description of the context, followed by a theoretical and methodological reference framework, then the economic valuation exercise is carried out and the values projected, to finally determine the incremental effects of an event occurred more than 10 years ago.

Map 1. Location of Dams- Anchicayá's project

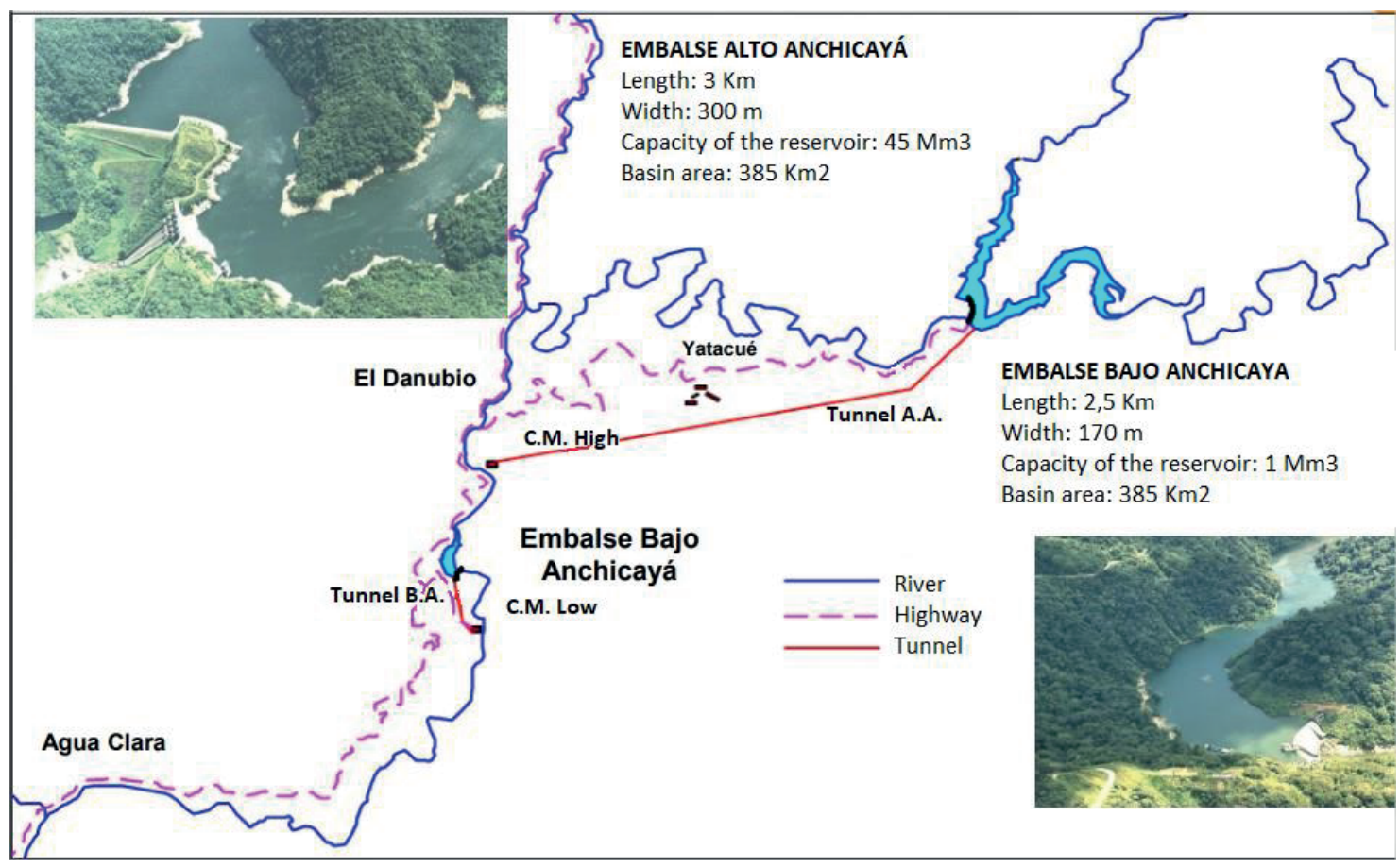




\section{Context}

As previously mentioned, the Anchicayá river project has two dams, which are located within the perimeter of Los Farallones de Cali natural park; the first dam came into operation in 1955, while the second in 1974 (Map 1).

According to the Defensoría del Pueblo (2007) after the mud discharge by EPSA, who opened the gates of the Bajo Anchicayá dam with the purpose of lowering the level of the dam, a judicial litigation between EPSA, the Regional Autonomous Corporation of Valle (CVC) and the afro-Colombian community of the Anchicayá River began in order to determine the amount of money the company has to pay for the damages, which has passed through the Ministry of Environment (currently, Ministry of Environment and Sustainable Development), judges, courts, the Constitutional Court, Council of State and even the Inter-American Commission of Human Rights (CIDH). Currently, the Council of State, who will have to determine the compensation to which those affected by the phenomenon are entitled, who are still without a fish and without compensation, is evaluating the case.

\section{Theoretical framework}

Regularly, an economic system is composed of a set of activities that recreate the material life of a society (Pearce and Turner, 1995). In a capitalist system, this means to articulate production, where natural resources are captured to be transformed into goods and services, if the distribution process is added to this, the exchange becomes possible under a monetary denominator such as price, allowing the meeting between buyers and sellers in the market.

Thus, the relationship between natural environments, economic activities and the way how the economy, as a scientific discipline, has discerned this relationships is based on three fundamental parameters, to wit: the laws of thermodynamics and their impact on the notion of progress, the functions performed by the natural resources in the economic process, and their vision according to the ecological limits (Labandeira and Vásquez, 2007).
Likewise, the natural system, conceived as a support element of the entire economic system, demonstrates the interconnections generated between each element, which unfold the laws of thermodynamics, given that each relationship as a flow's generator between activities and actors embodies the transformation of matter into energy or vice versa (Tietenberg, 2002). Thus, the exercise of anthropic activity, according to the magnitude and extension of the impacts, may end up violating the limits and carrying capacity of the ecological environment. That is to say, the availability of natural resources for production processes depends on the rate of use and regeneration of the same, while the exploitation carried out (except in the case of non-renewable resources) beyond their natural replacement rates, generates problems of overextraction and depletion of resources as supplies, including the generation and dumping of waste, alter in some way the environment's capacity to assimilate them, so the accumulation of waste is above the absorption capacity, thereby deteriorating the environment and creating pollution issues (Pearce and Turner, 1995).

Under these circumstances, when there is an alteration in the quality of the environment caused by human activities, the literature about that topic speaks of an environmental impact or negative externality (Orea, 1999). In this way, the mud discharged by the Bajo Anchicayá hydroelectric plant seems to have unleashed an arduous and extensive discussion about the multiplying effect that generated the contamination of the river (Corte Constitucional, 2012). Consequently, we seek to estimate the magnitude, extent and duration of the alteration caused by the anthropic action in order to assess the environmental impact (Canter, 1998).

It is considered then, that the environment and natural resources are priceless goods (Botero, 2003); for this reason, there is a measuring incommensurability. Thus, the traditional economy revolves around externalities, which appear when economic benefits and costs are not reflected in economic decisions, wherefore they are not reflected in the market, which is why a series of methodological instruments and techniques such as Environmental Impact Assessment (EIA), Environmental 
Management Plan (EMP), Contingency Plan (PDC) try to respond to the impact generated by this type of hydroelectric projects.

Hence, environmental degradation has been considered a market failure, while commercial exchange constitutes a system that operates with incorrect information about the value of nature and works as if it was costless or its price was zero. The main goal of the assessment as a means to facilitate decision-making is to highlight changes in the endowment of environmental resources in terms of relative or absolute scarcity (Pere-Riera, García-Pérez, Kriström, and Brannlund, 2005). So, the ultimate goal of the economic assessment of environmental impacts is to find out how the change that starts in the well-being of people can be translated into monetary units by altering the quality of the environment, even through economic methods such as environmental assessment (Botelhoa et al, 2017). However, the evaluation of these changes exceeds the work of brokering prices when allocating resources in the socio-productive spectrum, so that the fundamental evidence to estimate the value of an environmental asset seems to fall on the people whose lives were or are being affected (Cerda, 2009).

In this sense, the theoretical basis to deal with this type of problems begins with the definition of Total Economic Value (TEV), which is determined as the sum of the values of use, plus the non-use values of a natural resource and / or environmental resource considered inside a system that exchanges mass and energy flows. In other words, the total value of the available natural stock is the aggregation of the values of its current use and its potential use. Therefore, the TEV is translated in terms of maximum willingness to pay and keeps a classification of values; these values of use correspond to the benefits the people get from a product or service acquired in the present and future. That means, those referring to the consumption of the service and / or to the existence of directly productive capital (Ministerio de Medio Ambiente y Desarrollo Sostenible and Autoridad Nacional de Licencias Ambientales, 2017).
Generally, these environmental goods and services are not usually commercially exchanged, however, in some cases they are, allowing their marketing potential to be easy to model. Thence, the values of direct use comprise the subsistence activities carried out by the communities living close to a natural or environmental asset, as well as the usufruct of this asset for recreational activities or sports (fishing, hunting, wood, etc.). Meanwhile, the indirect use value (functional benefits) refers to sustenance or support given to economic activities related to production's value variation or the consumption of derived goods (Ministerio de Ambiente y Desarrollo Sostenible, 2007). Particularly, these kinds of contributions are not commercialized because they are regarded as public services without a market like hydric regulation and recharge.

In addition, the values of option refer to the possibility of having such services in the future. While non-use values set off from the fact that people can assign a monetary equivalence to natural resources whether they are used in the present or not. In turn, they are classified within the value of inheritance and existence based on a driver other than their use, such as the presence of the asset as a species, or the possibility of transferring that to other generations (Vega, 2014).

For this case, although it is true that natural sediments are necessary and important for the regulation of nutrients and maintenance of ecosystems downstream, it all seems to indicate that the load excess negatively impacted the normal rhythm of the activities contemplated in the economic system, generating an impact in detriment of value. According to Silva (2012), when discussing negative effects on the environment, it is so considering those that the evaluator regards in the context of a complete analysis of affectations and benefits as loss of natural, aesthetic-cultural, landscape and ecological productivity value among other environmental risks that lead to a disagreement with the ecologicalgeographical structure. Meanwhile, for the same author, an environmental damage is 
any material or moral decrease suffered by a person caused in contravention of a legal rule and that another is held accountable for (Silva, 2012).

This way, environmental changes have repercussions in the form of welfare modifications and these bestow importance on the total economic value (TEV) as an appraisal concept, which focuses on the fact that any type of natural and / or environmental resource must display amounts different to a direct use. In fact, it is possible that both users and non-users of the resources, as well as current and potential uses may reveal the TEV. Nevertheless, given the connotation of the lawsuit, and the cultural restrictions in terms of value, we assumed that $30 \%$ of the economic relations are capitalist and mercantile-natured and that the losses in the matter of goods and ecosystem services brought about a cost of opportunity.

In this way, an analysis was attempted in order to recognize the nature of the impacts on the well-being of the affected communities in view of the material reproduction of the goods and services provided by their habitat as a general life support.

\section{Methodology}

There are two main approaches to obtain information on the demand and value of an environmental good or service (Mendieta, 2005). This is, firstly, the direct estimation of the value based on observations of individuals' behavior in hypothetical markets, where observations about their willingness to pay and willingness to accept are involved, as compensation schemes; and others called indirect, where relationships are established between demands for private goods that are traded in conventional markets and unobservable demands for environmental goods or services related to the private good. This group also includes methods that attempt to measure the dose-response relationship between an environmental impact and its effects on health or physical depreciation of material assets or specific ecosystems that are affected (Azqueta, 1996; Herruzo, 2002).

You can locate the hedonic pricing method associated with the value of the housing, the cost of traveling, related to the amount of displacement towards an environmental asset or service and the avoided costs, which go to the expense for anticipated damages. But when unobserved, instruments such as the contingent valuation that seeks to simulate it especially when it comes to indirect use value are sought out.

Although it is similar to the technique of assessing changes in productivity, the lossof-profit method reckons changes in human productivity resulting from negative effects on health due to pollution or environmental degradation or changes in the availability of natural resources. While the loss of earnings (salaries) and medical expenses, resulting from environmental damage on health, are assessed and considered as losses of profit or human capital, this approach can be useful in industrial or road safety and in projects that affect air quality.

On the other hand, costs of opportunity are based on the idea that the costs of using a resource for purposes that do not have market prices or are not commercialized, can be estimated using the income lost for not putting the resource to other uses as a variable. For example, in preserving an area for a national park instead of using it for agricultural purposes, the lost income in the agricultural activity represents, in this case, the cost of opportunity of the park, thus, instead of directly assessing the benefits of the park, the income not earned for preserving the area is estimated, which is why it is also considered as the cost of preservation.

Under another perspective, the market price method estimates the economic valueof the ecosystem's products and / or services that are bought and sold in commercial markets, and it is used to quantify the value changes in the quantity or quality of a good or service. In the same way, the range of alternatives to apply them are classified into: a) changes in productivity (using normal or corrected economic means, when there are market distortions of goods and services); b) Illness cost (quantifies the costs that an individual must incur to treat the disease); and c) human capital costs, in this case related to the loss of productivity of human beings caused by premature death (Ministerio de Ambiente y 
Desarrollo Sostenible and Autoridad Nacional de Licencias Ambientales 2017).

In most cases in which the contingent valuation method is used, it is to simulate a market in order to collect information through surveys and in this way determine marginal valuations facing the variation of the environmental environment in terms of both benefits, but also damages and harms. Thus, the individual is asked what would be the maximum willingness to pay or the minimum willingness to accept (DAA) for the change in the environmental good.

Having said that, the high costs of the implementation of these methodologies, such as the contingent valuation, the cost of travel, and the hedonic pricing method, lead to estimations called "Benefits transfer method" or "the transfer method of environmental values."(Loureiro and Loomis, 2017). The procedure itself aims to determine the economic value of an environmental good or service provided by the ecosystem under study, starting from a similar place and good of a different context, using its monetary estimate of the latter to transfer it to the former. It noteworthy that the process generally involves the direct transfer of benefits or the transfer of a benefit function (Carriazo, Ibáñez, and García, 2003).

However, for Osorio (2006) there are three ways to do it: The transference of points or the punctual estimation, the transfer of the measures of the central tendency (statistics) and the transfer of specialist's judgment or administrative measures. In the first case, a similar place is estimated and the parameters defined, later these are translated comparatively against the place where the primary study is to be applied. For the second one, the experts judgment, studies and evaluations of panel data and also of advanced indicators can be carried out, as well as the opinion of experts. Finally, in the transfer of functions, a model with variables in arrays (of the vector type) is created and used as the site where the valuation process is applied.

Finally and to conclude this section, it is necessary to point out with Herruzo (2002), that the analyst should not only address one of the methods indicated above, since the tracking of preferences associated with the methods of economic evaluation can be measured in other ways different to willingness to pay and willingness to accept a compensation, for example through voting processes or through content techniques that might be more qualitative-natured (Kassarjia, 1977).

The damming of large tropical rivers for the generation of electrical energy, ordinarily triggers a diverse set of environmental alterations, these have repercussions on issues such as the articulation of sensitive activities within economic systems such as consumption, production, surplus distribution, along with other related ones such as fish populations and the productivity of ecosystems (Obade and Lal, 2014). When the damming is located on the main trunk of the fluvial system, the effects on the ichthyofauna are of great magnitude, especially when the migratory species constitute the base of the fishing resource, as it is the case of the rivers of the floodplain of Colombian Pacific.

Although, there is not much literary background on this type of cases concerning the efflux of sludge in the Anchicayá river basin in the Colombian Pacific, as well as evaluation and assessment of its impacts, the evaluative work is done while adapting to the circumstances at hand, that is how different methods of social inquiry are used in order to get to ultimate goal of a monetary estimate of the impact. In this way, the following steps were determined:

1. A documentary analysis was performed, based on the reading and analysis of the judicial files, in order to know the background and establish the meaning and scientific scope of the evidence accepted.

2. An interview was conducted with the aim of establishing the appreciation of the stakeholders involved (affected Communities vs. EPSA) regarding the gap created between supply (before impact) and environmental demand (after impact). This in order to reconstruct the action scenarios of the two stakeholders, their pressure on natural resources, the characteristics and weightings on degraded natural capital. It is worth saying that, in the case of the communities and in 
the spirit of achieving some degree of aggregation of preferences, participatory workshops were held in the three sensitive points of the problem: the upper, middle and lower (maritime area).

3. Secondary information was examined in order to analyze the degree of coherence between the perceptions and the documentary record.

4. The valuation alternatives against the information available were reviewed in order to establish an evaluation model on direct and indirect use values.

5. Based on this, the 2014 values projection was raised.

Since the economic evaluation of environmental damage depends on the main components (biophysical damage and social damage) to establish the biophysical damage, it was necessary to determine the type of alteration caused and its relationship with the natural resources affected, considering the composition of resources in both the site of the disaster as in the area of influence (area outside the project that is altered by the action). In addition thereto, there is the evaluation of the social damage that requires knowing the social benefits that ceased to be perceived after the affectation of the natural resource (Botelhoa et al, 2017; Barrantes and Di Mare, 2004).

The emphasis of the analysis on this particularity sets off from the performance of the company that generated several impacts that are summarized in the measurable incremental effect in terms of the environmental offer before the 2001 event and the environmental demand caused thereafter.

With this, the resulting differential was examined in terms of the total economic value, so that:

$\mathrm{TEV}=\mathrm{VU}+\mathrm{VNU}=(\mathrm{VUD}+\mathrm{VUI}+\mathrm{VO})+$ $(\mathrm{VE}+\mathrm{VL})$

Where:

VU: Use value

VNU: Non-use value
VUD: Direct use value

VUI: Indirect use value

VO: Option value

VL: Legacy value

VE: Existing value

TEV: Total economic value

As already mentioned above, the study falls on the direct and indirect use value estimating losses on agriculture and fisheries nonetheless. In fact, it started from recognizing the losses caused in the middle and upper areas of the river for the first case in terms of crops of chontaduro, borojó, cane, corn, papachina, and bananas, among others; conversely, in the maritime zone (low zone), the coconut palm and other crops were considered on a smaller scale, such as cane, papachina, and bananas. Likewise, fish species such as streaked prochilod, sabaleta gualajo, pelada, shrimp and molluscs (such as piangua) were involved. This way was assumed the loss of private and market goods, considering the variation in the values of agricultural production and fish catching, as well as consulting the differential effect on the values (prices by quantities) of the products traded before and after the event. That is why we use an indirect estimation method such as changes in productivity and loss of benefits.

With the above, the generation of value in the area depends on the support provided by the natural capital and the ecosystem supply, this involves a series of goods and services without a market (public good) and with the shortage of time and budget constraints, in that way, it is decided to gear the study towards the profit transfer method.

It must be added that, as the damage assessment involves defining the zone and the impact's lingering time. Based on the information provided by the actors and the knowledge of the experts in that area, the multidisciplinary professional group was able to determine that the effects lasted for about 3 years. Meanwhile, the area considered for the impact-of-the-discharged-sediments analysis was estimated for a length of 60 kilometers (the length of the river to the community of Coco) taking both margins of the river. 
Additionally, a total of 15 communities (3087 inhabitants approximately) belonging to five Community Councils.

Finally, the differential to be compensated is obtained by adjusting to the expression of the present sum (P) and a series of uniform sums such that:

$$
P=R\left[\frac{(1+i)^{t}-1}{i(1+i)^{t}}\right]
$$

Where:

$\mathrm{R}$ : the differential gross value of goods loss and services traded after 2001

$\mathrm{p}$ : Value of the present sum to be compensated until 2014

$t$ : time

$i$ : Interest rate (opportunity cost)

To calculate the material losses, differences are established in the value of the product (prices by quantities) before and after the accident, and valued at average current prices of 2001 (July 2001) and the corresponding values of 2004. This establishes percentages of damage attributed to the phenomenon for four years, inasmuch as the first year assumes an imputable $80 \%$, the second year $70 \%$, the third year $60 \%$ and finally $50 \%$. For example, data on catches, production and losses (differential effect) are assumed from 2001 to 2014. Then, the values are deflated by the producer price index (base 2006) by putting them at constant prices of the base year. Subsequently, the losses are projected and taken to net present value at an opportunity rate of $4 \%$.

This is intended to compensate the losses suffered by the population involved, adding the values of direct and indirect use, without considering the loss of purchasing power over time and the opportunity cost of capital, that is, assuming that during all this time the harmed population counted on a banking performance brought to values of today.

\section{Results}

The economic dynamics of the region, in this case the Anchicayá territory, are based on its natural resources from which the products are extracted thus enabling the community's self-sufficiency and allowing some level of trade, with regional and national markets, for products from fishing, mining, hunting, agriculture, shell harvesting and timber extraction, considered as the main productive activities of this territory, developed by the communities living near the river, as well as by external stakeholders that promote extraction of resources at a larger scale, like the hydroelectric power station.

However, with the sudden discharge of approximately 500,000 cubic meters of contaminated sediment in July 2001 (with hydrocarbons and heavy metals) by the hydroelectric dam, high-intensity and broadscope shocks were caused on the ecosystem, disturbing the vast majority of flora and fauna in the place, it even succeeded unleashing a series of alterations to the socio-economic and environmental equilibrium of the flooding zone of the alluvial and fluvialmarine terraces and the alluvial plain of estuaries and streams. The reaction in the economic subsystem began promptly; feeding, transportation, and traditional mechanisms of social cohesion were affected. When flood areas do not receive the necessary nutrients, the entire ecosystem is altered, and the nutrient's exchange that maintains the regeneration of soils and the conditions that safeguard the production in an agro-ecological system is lost. But in the opposite direction, due to an abrupt and uncontrolled discharge, the water and sediments contamination suddenly infiltrates the river-sea frame with consequences on trophic chains; activities such as fishing and agricultural lands lower their productivity leaving non-minor impact.

One of the assumptions implicit in the calculation is that sea fishing is done by journeys in two to four days, averaging 4 journeys per month, per fisherman. Thence, the values at current prices yielded the following result Table 1.

While crustaceans and mollusks yielded Table 2.

Subsequently, a similar approach was taken for agricultural production Tables 3, 4.

Now, when processing the information and after estimating the average annual 
Table 1. Gross value of the fish catch (2003-2004) at current prices (pesos)

\begin{tabular}{|c|c|c|c|c|c|c|}
\hline \multirow{2}{*}{$\begin{array}{l}\text { Zone of life/ } \\
\text { Period }\end{array}$} & \multicolumn{3}{|c|}{ Before July 2001} & \multicolumn{3}{|c|}{ After July 2001} \\
\hline & $\begin{array}{c}\text { Quantity kg } \\
\text { (month) }\end{array}$ & $\begin{array}{l}\text { Price } \\
\text { mean }\end{array}$ & Total value & $\begin{array}{l}\text { Quantity kg/ } \\
\text { month }\end{array}$ & Price & Total value \\
\hline High & 300 & 7000 & 2100000 & 75 & 8000 & 600000 \\
\hline Medium & 375 & 7000 & 2625000 & 275 & 8000 & 2200000 \\
\hline Low & 1200 & 7000 & 8400000 & 25 & 8000 & 200000 \\
\hline $\begin{array}{l}\text { Total Sub basin } \\
\text { (Month) }\end{array}$ & 1875 & & 13125000 & 375 & & 3000000 \\
\hline Total ( year) & 22500 & & 157500000 & 4500 & & 36000000 \\
\hline
\end{tabular}

Source: Calculation by the authors based on fieldwork, interviews, expert consultants and Gómez (2010).

Table 2. Gross value of the crustacean and shellfish catch (2003-2004) at current prices

\begin{tabular}{|c|c|c|c|c|c|c|c|c|}
\hline \multirow[b]{2}{*}{$\begin{array}{c}\text { Life zone } \\
\text { (value) / } \\
\text { Period }\end{array}$} & \multicolumn{4}{|c|}{ Before July 2001} & \multicolumn{4}{|c|}{ After July 2001} \\
\hline & $\begin{array}{c}\text { Shrimp } \\
\text { (kg mean / } \\
\text { month) }\end{array}$ & $\begin{array}{c}\text { Crab (kg } \\
\text { mean / } \\
\text { month) }\end{array}$ & $\begin{array}{l}\text { Piangua } \\
\text { (Dozen } \\
\text { average } \\
\text { month) }\end{array}$ & $\begin{array}{l}\text { shrimp } \\
\text { (kg mean } \\
\text { / month) }\end{array}$ & $\begin{array}{c}\text { Shrimp } \\
\text { (kg mean / } \\
\text { month }\end{array}$ & $\begin{array}{c}\text { Crab (kg } \\
\text { mean / } \\
\text { month) }\end{array}$ & $\begin{array}{l}\text { Piangua } \\
\text { (Dozen } \\
\text { average } \\
\text { month) }\end{array}$ & $\begin{array}{c}\text { Shrimp } \\
\text { (kg Mean } \\
\text { / month) }\end{array}$ \\
\hline Medium & 5965800 & 7200000 & 562500 & 0 & 328000 & 1700000 & 337500 & 0 \\
\hline Low & 12444000 & 15000000 & 1350000 & 1600000 & 696000 & 3400000 & 505800 & 1452000 \\
\hline
\end{tabular}

Source: Calculation by the authors based on fieldwork, interviews, expert consultants and Gómez (2010).

Table 3. Gross values of agricultural production at current prices (Before July 2001)

\begin{tabular}{|l|l|l|l|l|l|l|}
\hline $\begin{array}{c}\text { Life zone } \\
\text { (value) / Period }\end{array}$ & \multicolumn{1}{|c|}{ Borojo (kg) } & Chontaduro (kg) & \multicolumn{1}{|c|}{ Coconut } & Cain (kg) & Bananito & Papachina \\
\hline High & 2905798000 & 1297230000 & 755504750 & 20755500 & 108022000 & 1004016050 \\
\hline Medium & 2905798000 & 1297230000 & 755504750 & 20755500 & 108022000 & 1004016050 \\
\hline Low & 37808400 & 0 & 2457516880 & 21604400 & 108022000 & 820974800 \\
\hline
\end{tabular}

Source: Calculation by the authors based on fieldwork, interviews, expert consultants and Gómez (2010).

Table 4. Gross values of agricultural production at current prices (After July 2001)

\begin{tabular}{|l|l|l|l|l|l|l|}
\hline $\begin{array}{c}\text { Life zone } \\
\text { (value) / Period }\end{array}$ & \multicolumn{1}{|c|}{ Borojo (kg) } & Chontaduro (kg) & \multicolumn{1}{|c|}{ Coconut } & \multicolumn{1}{|c|}{ Cain (kg) } & Bananito & Papachina \\
\hline High & 21585928000 & 1206423900 & 3819035000 & 10211706 & 56171440 & 507292320 \\
\hline Medium & 21585928000 & 1206423900 & 3819035000 & 10211706 & 56171440 & 507292320 \\
\hline Low & 7021560 & 0 & 621130640 & 10629364 & 14042860 & 103702080 \\
\hline \multicolumn{7}{|r}{ Source: Calculation by the authors based on fieldwork, interviews, expert consultants and Gómez (2010). } \\
\hline
\end{tabular}

Table 5. Total calculation of agricultural losses, fishing and shellfish (at constant 2006 prices) and future value to be compensated

\begin{tabular}{|l|c|c|c|}
\hline Estimated Loss / Relative Decrease & Total Lost & Anual average & Future Value \\
\hline Fish, crustaceans and molluscs & 1092258407 & 273064602 & 472859540 \\
\hline Agriculture & 6071336867 & 1517834217 & 2628397765 \\
\hline Interest rate & 0,04 & & \\
\hline Time & 14 & & 3101257304 \\
\hline Total & & \\
\hline \multicolumn{2}{|r|}{ Source: Calculation by the authors based on fieldwork, interviews, expert consultants and Gómez (2010). } \\
\hline
\end{tabular}


differential effect (placed at constant 2006 prices) with the scenarios attributable to the impact, the calculations yielded the following results Table 5 .

After the previous calculations, approximately 3.102 million pesos should be the compensation to the community living next to the impact.

\section{Discussion}

Around the studies and available information, which was used to aggregate and support the study, there are periodicity and integrality issues. Papers about socioeconomic and cultural practices in the Colombian Pacific are found, written by authors like Oslender (2004) and Escobar, (2012), in addition to more sectoral works such as Pérez's (2008) who addresses the economic problems of the municipality of Buenaventura; a matter that in the first case gives a general idea of the relationship between communities and their harnessing of natural resources, understood in the cultural and general environment of the afro-Colombian population along the Chocó bio-geographical, which is why the specific context of a municipality bathed by a series of rivers is left unattended, which includes a central port where the largest international trade in Colombia takes place and where the dynamics of the rural area (including the population near the maritime and fluvial zones) and urban area (Concentrating habitat and division of labor) come together. In the second case, although a reference is made to the specific context of Buenaventura, it is exclusively urban, leaving out the dynamics and logic of life in the surrounding rivers without discounting life in the communities of the basin around a hydroelectric megaproject like the one in anchicayá.

Much of the support for this documentary work is based on documents such as CVC reports, the Secretary of Agriculture of Valle del Cauca, Earth Economics, the Ministry of the Environment, the environmental management plan of the basin and the documents of the judicial dependencies, among others.

\section{Conclusions}

Indeed, it is evident that the economy of the Anchicayá area is strongly linked to the existing natural capital, despite the fact that the results in terms of accumulation and reproduction of the surplus, when used in the traditional economic analysis, did not appear in the internal return rates of the territories that surround the river. The line of capitalization would fall in the self-investment of care and the environmental offer that is erected in the representation of progress that agricultures and the afro-Colombian communities hold under the African ancestral legacy. Thus, the dichotomist nature-culture relationships do not exist and on the contrary, it can be deduced that there is a symbiosis between these two elements, giving rise to a type of development (Restrepo, 1999, Escobar, 2012).

On the other hand, the zone considered for analyzing the impact of the sediments discharged on the effluent is constituted by an area of land on both banks of the river, for a length of 60 kilometers. The impact includes the flooding of the alluvial and fluvial-marine terraces and the "vegas" (fertile lands watered by a river) of estuaries and streams. The first approaches allow to infer that the initial impact was very high and has been decreasing, but the natural recovery (resilience) has been very slow, perhaps because remedy actions were not executed (Briceño, Flores, Toledo, Aguilar Gonzáles, Batker, and Kocian, 2013).

Consequently, the effects can be seen in the low production of fish, shellfish and agricultural products, to these must be added the loss of land, the fall in the collection of mollusks and crustaceans from the mangrove, the infrastructure of drainages and the difficulties for transport, effects that according to the exposed calculations must be compensated and distributed among the affected community. 


\section{References}

Azqueta, D. (1996). Valoración económica de la calidad ambiental. Madrid, España: Mc Graw Hill.

Barrantes, G., y Di Mare, M. (2004). Metodología para la evaluación económica de daños ambientales en Costa Rica. Sostenibilidad. Heredia, Costa rica: Instituto de Políticas para la Sostenibilidad.

Botero, E. U. (2003). Introducción a la valoración ambiental y estudios de caso. Bogotá, Colombia: Universidad de Los Andes.

Botelhoa, A., Ferreirab, P., Limac, F., Costa Pintod, L., \& Sousae, S. (2017). Assessment of the environmental impacts associated with hydropower. Renewable and Sustainable Energy Reviews, 70, 896-904.

Briceño, T., Flores, L., Toledo, D., Aguilar Gonzáles, B., Batker, D., y Kocian, M. (2013) Evaluación Económico-Ecológica de los Impactos Ambientales en la Cuenca del Bajo Anchicayá por Vertimiento de Lodos de la Central Hidroeléctrica Anchicayá. Tacoma, USA: Earth Economics.

Canter, L. (1998). Manual de evaluación de impacto ambiental: técnicas para la elaboración de los estudios de impacto. Madrid, España: McGrawHill interamericana de España.

Carriazo, F; Ibáñez, A; y García, M. (2003). Valoración de los Beneficios Económicos Provistos por el Sistema de Parques Nacionales Naturales: Una Aplicación Del Análisis de Transferencia de Beneficios (p. 43). Bogotá, Colombia: Universidad de los Andes.

Cerda, A. (2009). Valoración económica del ambiente. Recuperado de https://www. cepal.org/ilpes/noticias/paginas/8/35988/ ivaloracioncepal2009.pdf

Corte Constitucional. (2012). Acción de tutela instaurada por la Empresa de Energía del Pacífico S.A. E.S.P. EPSA E.S.P., contra las actuaciones y decisiones judiciales adoptadas por el Tribunal Administrativo del Valle Cauca con ocasión en la Acción de Grupo No. 200204564-01. T-274/12. Bogotá, Colombia: Gaceta de la Corte Constitucional.

Defensoría Del Pueblo. (2007). Informe de seguimiento a la resolución defensorial $\left(N^{\circ}\right.$ 35). Situación ambiental del Río Anchicayá. Recuperado de http://www.defensoria.gov.co/ es/public/Informesdefensoriales/862/Informede-seguimiento-a-la-Resoluci\%C3\%B3nDefensorial-Regional-No-35-Situaci\%C3\%B3n-
ambiental-del-R\%C3\%ADo-Anchicay\%C3\%A1--Buenaventura-Valle-del-Cauca.htm

Empresa de Energía del Pacífico. (2015). Gestión de sedimentos en centrales hidroeléctricas: Bajo Anchicayá. Recuperado de https://www.cno.org. co/sites/default/files/documentos/noticias/3-

FRANCISCO\%20M.Taller sedimentos acolgen_27_05_2015\%28final\%29.pdf

Escobar, A. (2012). ¿Cómo pensar la relación entre ser humano y naturaleza? Más allá del Tercer Mundo Globalización y Diferencia. Historia. Bogotá, Colombia: Instituto Colombiano de Antropología e Historia.

Garmendia, A., y Crespo, C. (2005). Evaluación de impacto ambiental. Madrid, España: Pearson.

Gómez, E. P. (2010). El mercado de pescado en la ciudad de Bogotá. El mercado de pescado en las grandes ciudades latinoamericanas. Bogotá, Colombia: CFC/FAO/CFC/FAO/INFOPESCA

Herruzo, A. (2002, julio). Fundamentos y métodos para la valoración de bienes ambientales. Comunicación presentada en las Jornadas Temáticas "aspectos ambientales de la agricultura". Madrid, España. Universidad Politécnica de Madrid.

Kassarjia, H. (1977). Content Analysis in Consumer Research. Journal of Consumer Research 4(1), 8-18.

Labandeira, X; León, C. y Vásquez, M. (2007). Economía Ambiental. Madrid, España: Pearson Educación S.A.

Loureiro, M. y Loomis, J. (2017). How Sensitive Are Environmental Valuations To Economic Downturns? Ecological Economics, 140, 235-240.

Mendieta, J. (2005) Manual de valoración económica de bienes no mercadeables: Aplicaciones de las técnicas de valoración de bienes no mercadeables y el análisis costo beneficio y medio ambiente. Bogotá, Colombia: Universidad de los Andes.

Ministerio de Ambiente y Desarrollo Sostenible y Autoridad Nacional de Licencias Ambientales, (2017). Criterios técnicos para el uso de herramientas económicas en los proyectos, obras o actividades objeto de licenciamiento ambiental. Recuperado de http://www.andi.com. co/Uploads/MADS\%20Resoluci\%C3\%B3n\%20 1669\%20de\%202017\%20Manual\%20ANLA\%20 -\%202017\%20-\%20Parte\%20B.pdf

Ministerio de Ambiente y Desarrollo Sostenible. (2007). Auto No. 1996 "por el cual se requiere información adicional". Recuperado de http:// 
www.minambiente.gov.co/images/normativa/ Otros/Autos/2007/auto_1996_310707.pdf

Obade, V. y Lal, R. (2014). Using meta-analyses to assess pedo-variability under different land uses and soil management in central Ohio, USA. Geoderma, (232), 56-68.

Orea, D. (1999). Evaluación de Impacto Ambiental. Madrid, España: Agrícola Española.

Oslender, U. (2004). Fleshing out the geographies of social movements: Colombia's Pacific coast black communities and the 'aquatic space'. Political Geography, 23, 957-985.

Osorio, J. (2006). El Método de transferencia de beneficios para la valoración económica. Semestre Económico, 18.

Pérez, G. J. (2008). Historia, geografía y puerto como determinantes de la situación social de Buenaventura. En J. Viloria (Ed.), Economías del Pacífico colombiano. Cartagena, Colombia: Editorial Nomos.

Pearce, D., y Turner, R. (1995). Economía de los recursos naturales y del medio ambiente. Madrid, España: Ediciones Celeste

Pere-Riera, M., García-Pérez, D., Kriström, B., y Brannlund, R. (2005). Manual de Economía Ambiental y de los Recursos Naturales. Madrid, España: Thomson.

Silva, B. (2012). Evaluación ambiental: impacto y daño. Un análisis jurídico desde la perspectiva científica (tesis doctoral). Universidad de Alicante: Alicante, España.

Tietenberg, T., \& Lewis, L. (2012). Environmental $\&$ natural resource economics. New Jersey, USA: Pearson Education, Inc.

Vega, J. (2014) Derechos patrimoniales de herencia y existencia. Conflicto y sociedad, 2, 89-108.

¿How to quote this article?

Cortés Landázury, R., Riascos López, A., \& Idrobo Salazar, W. (2019). Mud, value and welfare. An economic estimation of the impact in the Anchicayá river basin. Cuadernos de Administración, 35(63), 42-54. DOI: https://doi. org/10.25100/cdea.v35i63.6939 